\title{
SUCCESSION OF PERIPHYTON AND PHYTOPLANKTON ASSEMBLAGES IN YEARS WITH VARYING AMOUNTS OF PRECIPITATION IN A SHALLOW URBAN LAKE (LAKE JEZIORAK MALY, POLAND)
}

\section{ELŻBIETA ZĘBEK}

University of Warmia and Mazury, Faculty of Law and Administration, Law of Environmental Protection Laboratory, Warszawska 98, 10-702 Olsztyn, Poland; e-mail: elzbieta.zebek@uwm.edu.pl

\begin{abstract}
Zębek E.: Succession of periphyton and phytoplankton assemblages in years with varying amounts of precipitation in a shallow urban lake (Lake Jeziorak Mały, Poland). Ekológia (Bratislava), Vol. 33, No. 3, p. 259-273, 2014.

This study of periphyton assemblages (periphyton in separator pipes, epilithon and epiphyton) and phytoplankton was carried out in Lake Jeziorak Mały in 1997-2003 and 2005. Since precipitation amounts varied in these years, changes in the abundance, biomass, taxonomic group structure, species diversity and dominant taxa of these assemblages were analyzed in relation to the physical and chemical water parameters. The periphyton in pipes had their highest abundance and biomass at the mean precipitation in the vegetative season and at maximum precipitations in winter 2000 , and also in the 1997 vegetative season when there were high levels of electrolytic conductivity and orthophosphate and chloride concentrations. The assemblage was dominated by the diatoms Diatoma vulgaris which was resistant to washing and Navicula gregaria resistant to high amounts of organic matter. Similarly, maximum abundance and biomass of epilithon was found the maximum precipitation level. However, in 2003 there was a low precipitation level which favoured habitation by epilithic filamentous chlorophytes, especially Ulothrix tenuissima. Meanwhile, epiphyton and phytoplankton thrived best in the high precipitation conditions and moderate chloride concentration in 2001. These assemblages were dominated by species typical for eutrophic waters, such as Gomphonema olivaceum and Planktolyngbya brevicellularis. Differences in the dynamics of periphyton assemblages and phytoplankton in the studied years indicate varying succession rates in these assemblages, especially in the separator pipes and on stones. These phenomena are considered to be related to the different environmental conditions engendered by variable amounts of precipitation.
\end{abstract}

Key words: lake, littoral zone, periphyton, phytoplankton, succession, precipitations, environmental conditions.

\section{Introduction}

Ecological succession is an orderly community with a controlled process of ecosystem development, passing from initial colonisation of open, unoccupied habitats by pioneer communities, through a sequence of transitional stages, each dominated by later invaders, and culminating in a stabilized climatic ecosystem in which the maximum biomass achieves an equilibrium with 
available energy flow (Odum, 1969). Succession is an orderly process of directional changes in the species structure of the biocenosis, which may proceed for several hundred, or even several thousand years, or which may be a regular and repetitive sequence of changes in the biocenosis, resulting from cyclical environmental changes (e.g. annual plankton succession). Ecological succession may be divided into allogenic, driven by external environmental forces (e.g. climate changes), and autogenic, driven by the organisms themselves, where the process of replacing previous occupants by new ones is dependent upon the activity of other organisms altering the habitat (e.g. nutrient depletion) (Reynolds, 1980; Lampert, Sommer, 1996).

The development of periphyton and phytoplankton is often described on the basis of annual succession patterns (Sommer et al., 1986; Reynolds, 1993; Nõges, Laugaste, 1998; Irigoien et al., 2000; Nõges et al., 2003; Luttenton, Baisden, 2006). It is determined by numerous factors, such as seasonal changes in water temperature or solar radiation, or mixing and re-suspension of nutrients, including phosphorus, from the sediments (Sommer et al., 1986; Reynolds, 1988; Romo, Miracle, 1994; Wantzen et al., 2008). The annual succession patterns of algae may also be affected by biological interactions between organisms, such as competition for food, intensity of feeding and also grazing (Reynolds, 1980; Hansson, 1990; France, 1995; Azim et al., 2005).

In urban lakes, the succession of periphyton and phytoplankton assemblages may be conditioned by changes in environmental conditions, which can cause inflow of storm waters depending on the amount of precipitation. The changes in water quality in lakes can be rapid and extreme because of the nature of the inflow. This inflow can vary in terms of quantity, chemistry and seasonality, and these can depend on the location where unpredictable occurrences such as building construction or road salting in the surrounding catchments can often occur (Guzkowska, Gasse, 1990). Lake Jeziorak Mały is an example of a eutrophic lake with storm water inflows, and it therefore required protective-restoration measures to protect its waters. This especially involved the installation of lamella separators for storm water pretreatment. The aim of this paper is to determine the influence of varying levels of precipitation on the succession of periphyton and phytoplankton assemblages during 1997-2003 and 2005 in Lake Jeziorak Mały. The tested hypothesis is that storm waters affect the succession of periphyton and phytoplankton in Lake Jeziorak Mały differently in different years due to variable annual precipitation. Answers to the following questions were sought to verify this hypothesis:

1. Did storm water inflow significantly change the environmental conditions of periphyton and phytoplankton development in the years with varying precipitations?

2. Do quantitative and qualitative differences exist between periphyton and phytoplankton assemblages regarding physical and chemical water parameters in 1997-2003 and 2005 relative to the mean precipitation?

\section{Research area, material and methods}

Jeziorak Mały is a shallow (mean depth $3.4 \mathrm{~m}$ ) urban lake covering 26 ha in Mazurian Lakeland in north-eastern Poland. The lake can be recognised as a model lake. It is a eutrophic lake located in the moderate zone with a typical basin shape, shallow and isolated from other waterbodies. The lake is connected with Lake Jeziorak Duży by a narrow canal with a width of $4 \mathrm{~m}$ and depth of $4 \mathrm{~m}$. Due to the high disproportion between the surface areas of the lakes (26 ha and 3219 ha, respectively), the connection constitutes a concrete barrier used for water levelling. It is not a factor determining mixing of waters of both lakes. 
For many decades, this lake received untreated municipal sewage from the town of Iława. Since 1991, however, effluent has been treated at a local wastewater treatment plant. Work to improve the lake's water quality began in 1997 and has been ongoing since that time, including the installation of separators for the pre-treatment of storm water influent, and a fountain-based water aeration system. The lake shores were partly covered with concrete or reinforced with fascine, and most of the bottom was composed of stones and gravel. Lake Jeziorak Mały is therefore an example of a lake with reversed coastal zone management system (approx. 30\% macrophytes, 70\% concrete bank). Phytolittoral includes emerged macrophytes, mainly Phragmites communis, Scirpus lacustris (L.) Palla, Acorus calamus L., and Glyceria aquatica (L.) Wahlb., while the bottom was muddy and covered with decomposing plant debris.

Samples of periphyton were collected monthly from April to October in the years 1997-2003 and 2005, on the three substrates located in the littoral zone and phytoplankton in the pelagic zone of Lake Jeziorak Mały:

1. periphyton from the pipes of separators which drain storm waters $(\mathrm{S})$;

2. epilithon from the surfaces of stones accumulated in $1997(\mathrm{~K})$;

3. epiphyton from the floating leaves of vascular plants Acorus calamus L. ( R);

4. net phytoplankton from the $1 \mathrm{~m}$ euphotic zone in the pelagial (mean water transparency in the period 1997-2003 and 2005 amounted to $0.80 \mathrm{~m})(\mathrm{P})$.

The periphyton was scraped from the pipes, from $1 \mathrm{~cm}^{2}$ stones and from the macrophyte leaves which had been cut into 5-cm lengths. The pipes and stones were often found to be overgrown with Cladophora glomerata (L.) Kützing filamentous green algae, which forming a natural substratum for periphytic diatoms. The periphyton was shaken carefully in distilled water to separate algae and diatoms from chlorophyte thalli, and remains were scraped off macrophytes leaves with a knife. The samples were rinsed and preserved using an ethanol and a formaldehyde solution. The phytoplankton samples were collected with a Toń 5-L plankton sampler in the surface layer of the pelagic zone. The samples were poured through a $25-\mu \mathrm{m}$ mesh plankton net, and then preserved with Lugol's solution and a $4 \%$ formaldehyde solution. A total of 124 samples were collected. The following physical and chemical water parameters were determined: temperature $\left({ }^{\circ} \mathrm{C}\right.$ ), oxygen content $\left(\mathrm{mg} \mathrm{O}_{2} \mathrm{~L}^{-1}\right)$ (using an $\mathrm{HI} 9143$ oxygen meter), $\mathrm{pH}$, electrolytic conductivity $\left(\mu \mathrm{S} \mathrm{cm}{ }^{-1}\right)$ (using a CONMET 1 conductometer), and orthophosphate $\left(\mathrm{mg} \mathrm{PO}_{4} \mathrm{~L}^{-1}\right)$, silicon $\left(\mathrm{mg} \mathrm{Si} \mathrm{L}^{-1}\right)$, calcium $\left(\mathrm{mg} \mathrm{Ca} \mathrm{L}^{-1}\right)$, total nitrogen $\left(\mathrm{mg} \mathrm{N} \mathrm{L}^{-1}\right)$, iron $\left(\mathrm{mg} \mathrm{Fe} \mathrm{L}^{-1}\right)$ and chloride $\left(\mathrm{mg} \mathrm{Cl}^{-1}\right)$ concentrations (using a NOVA 400 spectrophotometer).

In the study plant periphyton and net phytoplankton were analyzed. The terms periphyton and phytoplankton concern all prokaryotic (cyanobacteria) and eukaryotic organisms among which diatoms, chlorophytes, dinoflagellates, chrysophytes and cryptophytes were analyzed. Qualitative and quantitative determinations of phytoplankton and periphyton were performed with an Alphaphot YS2 optical microscope at magnifications of $10 \times, 20 \times, 40 \times$ and $100 \times$. Diatom preparations followed standard procedures described by Battarbee (1979). Algae biomass was calculated for biovolume by comparing the algae with their geometrical shapes (Rott, 1981). Mean biomass was calculated for 10 individuals of each planktonic and periphytic algae species. For the purpose of levelling differences in densities of organisms in periphyton and phytoplankton, their numbers in each sample were determined in a planktonic chamber with a capacity of $1 \mathrm{~mL}$ in 5000 fields of vision with $20 \times$ magnification. The abundance and biomass of periphyton and phytoplankton was expressed in an identical and basic volume unit of $1 \mathrm{~mL}$. It was evidenced that in such a number of fields of vision, frequencies of occurrence of organisms in the assemblages were approximate. In all samples the coefficients of difference significance between the occurrence frequency of taxa of the assemblages and the coefficient common for the assemblages were high and statistically insignificant. Moreover, approximate values of coefficients of taxa occurrence frequency were recorded for all of the assemblages (Zębek, 2013).

Changes in the abundance and biomass of periphyton and phytoplankton assemblages were analyzed in 19972003 and 2005. Since the amounts of precipitation varied in these years, the monthly rainfall means in the Warmia and Mazury region during this period were obtained from statistical data held at the Olsztyn station (Grzesiak, Domańska, 1998-2004; 2006). The periphyton and phytoplankton species' diversity was analyzed to calculate the Shannon-Weaver index, which provides information on the species abundance and the distribution of particular periphyton and phytoplankton species (Shannon, Weaver, 1949).

\section{Results and discussion}

\section{General description of periphyton and phytoplankton assemblages and environmental conditions}

In eutrophic lakes, periphyte communities include a large proportion of diatoms, followed by filamentous chlorophytes and cyanobacteria, while the phytoplankton is often dominated 
by cyanobacteria. The dominance of diatoms in periphyton was recorded by a number of authors on a natural substratum (Kuczyńska-Kippen et al., 2004; Vogel et al., 2005 in epiphyton). In addition, diatom also dominated on the following artificial substrata (Bohr, Miotk, 1979; Hansson, 1990; Szlauer, 1996 recorded this on glass plates; Danilov, Ekuland, 2001 found them on substrata with PVC) reported this in eutrophic lakes. In lake Jeziorak Mały in 1997-2003 and 2005, periphyton ( $\mathrm{S}$ - periphyton in separator pipes, $\mathrm{K}$ - epilithon and R epiphyton) was dominated by diatoms in terms of both abundance and biomass, with a maximum of $90.47 \%$ for epilithon and $61.06 \%$ for periphyton in the separator pipes, accompanied by chlorophytes with a maximum of $42.50 \%$ for epilithon (Zębek, 2014). Both before and after introduction of restoration work, phytoplankton was dominated by cyanobacteria, which reached $92.83 \%$ of the total abundance in 1996 (Zębek, 2009) and 72.41\% in 1997-2003 and 2005, accompanied by diatoms at $31.99 \%$ and dinoflagellates at $14.59 \%$ (Zębek, 2014). The highest mean abundance was found for periphyton in the pipes $\left(70,535\right.$ ind. $\left.\mathrm{mL}^{-1}\right)$, and the lowest abundance for phytoplankton in the pelagial $\left(31,272\right.$ ind. $\left.\mathrm{mL}^{-1}\right)$. However, the highest mean biomass was recorded for epilithon at $0.226 \mathrm{mg} \mathrm{mL}^{-1}$ and the lowest for phytoplankton at $0.065 \mathrm{mg} \mathrm{mL}^{-1}$ (Zębek, 2013). Eutrophised lakes such as Lake Jeziorak Mały often recorded a predominance of cyanobacteria (Meffert, 1989; Nixdorf, 1994; Nixdorf et al., 2003; Kangro et al., 2005). This suggests that the structure of phytoplankton and periphyton in Lake Jeziorak Mały following the introduction of protective-restoration work was typical of eutrophic lakes.

T a b l e 1. Ranges of mean physical and chemical water parameters at sites with separators (S), stones (K), macrophytes (R) and the pelagial (P) in Lake Jeziorak Mały in 1997-2003 and 2005.

\begin{tabular}{|l|c|c|c|c|}
\hline Variable & $\mathbf{S}$ & $\mathbf{K}$ & $\mathbf{R}$ & $\mathbf{P}$ \\
\hline Water temperature $\left({ }^{\circ} \mathrm{C}\right)$ & $13.5-18.8$ & $17.9-20.2$ & $17.4-20.5$ & $17.2-21.2$ \\
\hline Conductivity $\left(\mu \mathrm{Sm}^{-1}\right)$ & $346-843$ & $320-626$ & $322-486$ & $323-522$ \\
\hline Orthophosphates $\left(\mathrm{mg} \mathrm{PO}_{4} \mathrm{~L}^{-1}\right)$ & $0.13-0.48$ & $0.31-0.94$ & $0.05-0.51$ & $0.01-0.45$ \\
\hline Silicon $\left(\mathrm{mg} \mathrm{Si} \mathrm{L}^{-1}\right)$ & $0.04-3.29$ & $0.60-1.09$ & $0.70-0.81$ & $0.53-3.12$ \\
\hline Calcium $\left(\mathrm{mg} \mathrm{Ca} \mathrm{L}^{-1}\right)$ & $7-182$ & $59-123$ & $73-159$ & $54-125$ \\
\hline Total nitrogen $\left(\mathrm{mg} \mathrm{N} \mathrm{L}^{-1}\right)$ & $0.5-3.0$ & $2.6-4.0$ & $1.8-3.0$ & $0.9-2.6$ \\
\hline Iron $\left(\mathrm{mg} \mathrm{Fe} \mathrm{L}^{-1}\right)$ & $0.05-4.36$ & $2.31-4.77$ & $0.05-4.75$ & $1.21-5.07$ \\
\hline Chlorides $\left(\mathrm{mg} \mathrm{Cl} \mathrm{L}^{-1}\right)$ & $18-97$ & $29-50$ & $22-47$ & $6-25$ \\
\hline
\end{tabular}

Inflows of nutrient-rich storm waters into urban lakes can change the lake's water chemistry, and thus change the living conditions for animal and plants organisms. Increased values of chemical parameters have often been recorded in these lakes. These included the conduc-

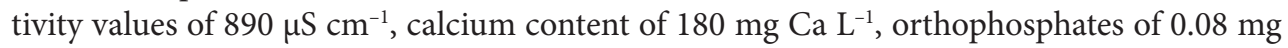
$\mathrm{PO}_{4} \mathrm{~L}^{-1}$ and silicon at $13.4 \mathrm{mg} \mathrm{Si} \mathrm{L}^{-1}$ (Guzkowska, Gasse, 1990). In this study, the following values were recorded at separators: (1) the lowest mean water temperature ranged from 13.5 to $18.8^{\circ} \mathrm{C}$; (2) the highest water electrolytic conductivity maximum was $843 \mathrm{mS} \mathrm{cm}^{-1}$ and (3) the highest concentrations of $\mathrm{Si}$, Ca and chlorides with maximums of $3.29 \mathrm{mg} \mathrm{Si} \mathrm{L}^{-1}, 182 \mathrm{mg}$ $\mathrm{Ca} \mathrm{L}^{-1}$ and $97 \mathrm{mg} \mathrm{Cl} \mathrm{L}^{-1}$ (Table 1). This illustrates the great influence of polluted storm-water inflow from the catchment area on the lake's water chemistry (Zębek, 2014). In addition, the 
highest mean orthophosphate and total nitrogen concentrations were recorded at sites with stones, with maximums of $0.94 \mathrm{mg} \mathrm{PO}_{4} \mathrm{~L}^{-1}$ and $4.0 \mathrm{mg} \mathrm{N} \mathrm{L}^{-1}$, while the highest temperature of $21.2^{\circ} \mathrm{C}$ and highest iron concentration of $5.07 \mathrm{mg} \mathrm{Fe}$ $\mathrm{L}^{-1}$ were registered in the pelagial surface layer (Table 1). These pelagial conditions suited the development of cyanobacteria, and this fact is supported by the positive correlation between their abundance and these existing water parameters (Zębek, 2014).

Dynamics of periphyton and phytoplankton assemblages in 1997-2003 and 2005

Differences in the mean abundance and biomass of periphyton assemblages ( $\mathrm{S}$ - periphyton in separator pipes, $\mathrm{K}$ - epilithon and $\mathrm{R}$ - epiphyton ) and phytoplankton (P) in Lake Jeziorak Mały were observed in 1997-2003 and 2005. Different dynamics were observed for periphyton in the separator pipes compared to other assemblages. The average highest abundance of these periphytic algae was 135,177 ind. $\mathrm{mL}^{-1}$ recorded in 2000 at high electrolytic conductivity, the lowest water temperature and a maximum orthophosphate level of $0.68 \mathrm{mg} \mathrm{PO}_{4} \mathrm{~L}^{-1}$. Meanwhile, the highest biomass was recorded at $0.65 \mathrm{mg} \mathrm{mL}^{-1}$ in 1997 immediately after activation of separators in the littoral zone. Differences in the abundance of periphyton in the pipes were related to orthophos-
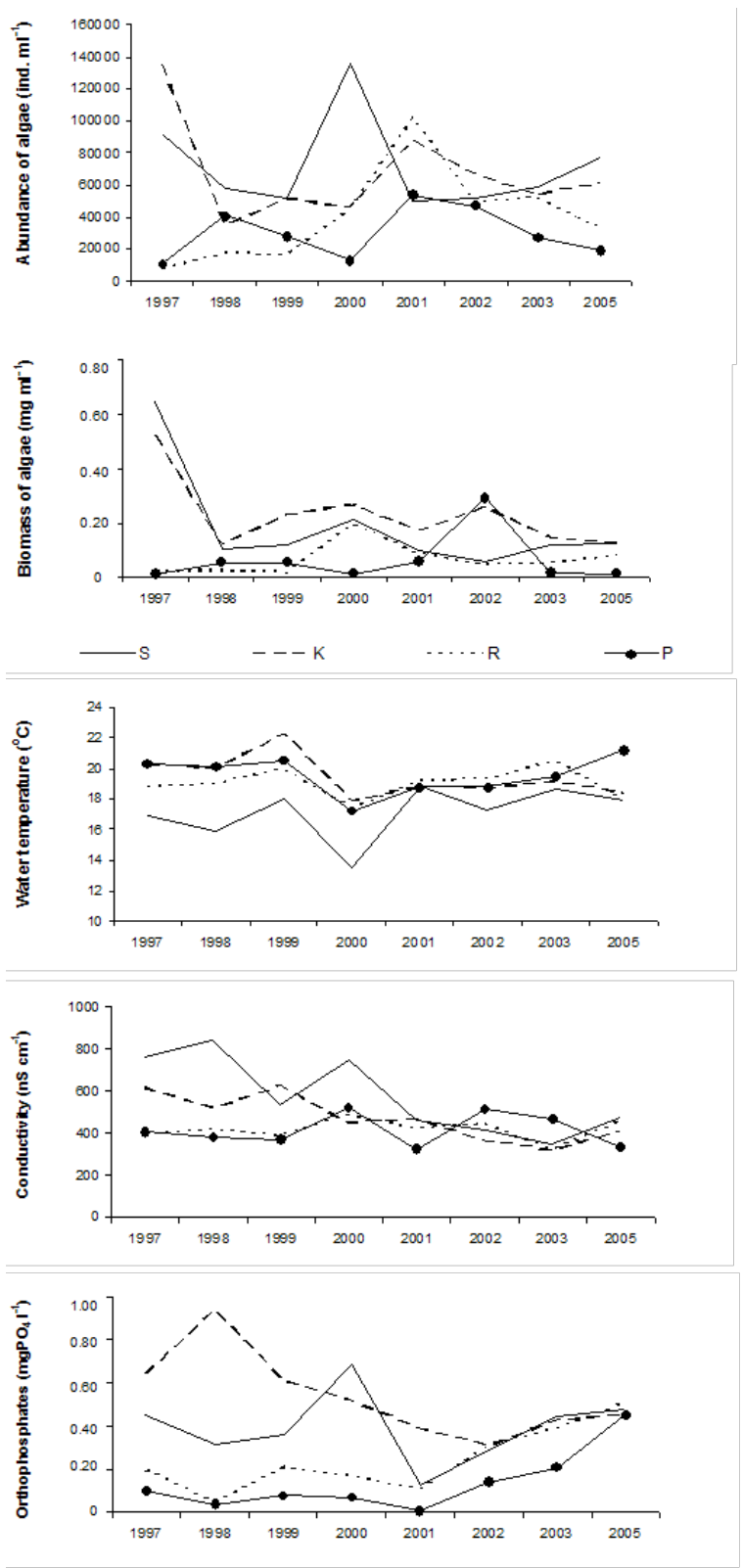

Fig. 1. Succession of periphyton assemblages ( $\mathrm{S}$ - periphyton in separator pipes, $\mathrm{K}$ - epilithon, $\mathrm{R}$ - epiphyton) and phytoplankton (P) (Zębek, 2012a) and changes in physical and chemical water parameters in 1997-2003 and 2005 in Lake Jeziorak Mały. 


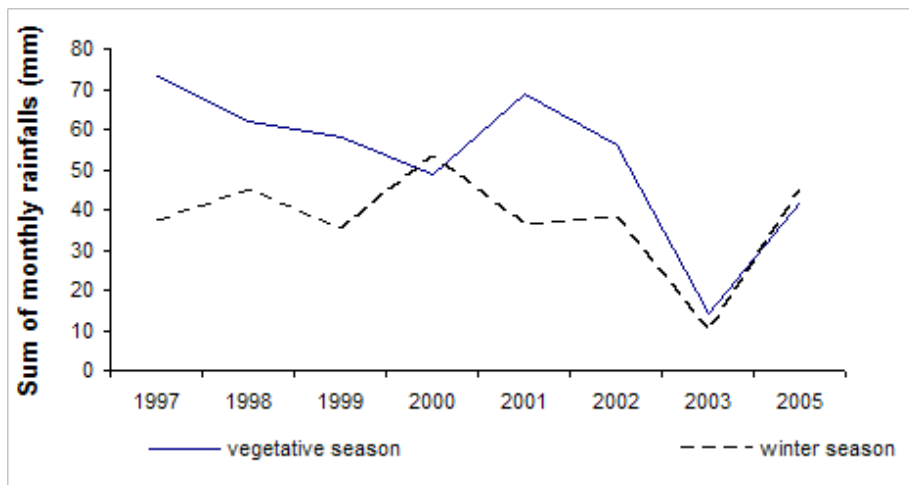

Fig. 2. Mean monthly amount of precipitation for the Warmia and Mazury region in 1997-2003 and 2005.

phate changes in the studied years (Fig. 1), and the suggestion that periphytic assemblage development was stimulated by this nutrient was completely supported by the statistically significant correlation between orthophosphate levels and the occurrence of species typical of periphyton in the pipes (Zębek, 2013). The epilithon abundance and biomass achieved their high levels in 1997, 1999 and 2001. The highest abundance and biomass of these algae were found in 1997 at 134,644 ind. $\mathrm{mL}^{-1}$ and $0.52 \mathrm{mg} \mathrm{mL}^{-1}$, respectively, when stones had accumulated in the littoral zone. The considerably lower orthophosphate levels in 1997 and 2001 were accompanied by high abundance and biomass of the epilithon. This may indicate the uptake of this nutrient by the periphytic algae, especially by the filamentous chlorophytes and diatoms (Zębek, 2013). Similar dynamics were observed in the studied years between epiphyton and phytoplankton. These algae achieved their highest abundances in 1998 and 2001 , with epiphyton registering 102,166 ind. $\mathrm{mL}^{-1}$ and phytoplankton 53,481 ind. $\mathrm{mL}^{-1}$ in 2001, at the highest water temperature and lowest orthophosphate levels. Meanwhile, the highest biomass of epiphyton was $0.20 \mathrm{mg} \mathrm{mL}^{-1}$ recorded in 2000, and for phytoplankton it was $0.29 \mathrm{mg} \mathrm{mL}^{-1}$ registered in the pelagial in 2002 (Fig. 1).

Long-term changes in the abundance and biomass of planktonic and periphytic algae in lakes can be related to alteration in hydrological conditions, such as changes in water level (Romo, Miracle, 1994; Nõges et al., 2003, 2010). In Lake Jeziorak Mały in 1997-2003 and 2005, a relationship existed between mean monthly precipitation and the abundance and biomass of periphyton assemblages and also phytoplankton, which was dominated by cyanobacteria. The mean sum of monthly precipitation for the Warmia and Mazury region was $49 \mathrm{~mm}$. Due to these factors, the following four situations were observed, as highlighted in Figures 1-3:

(1) Very low monthly precipitation amounts were recorded in both the vegetative and winter seasons of 2003 at 14 and $10 \mathrm{~mm}$, respectively. These were accompanied by very little storm water inflow, a moderate chloride concentration of $54 \mathrm{mg} \mathrm{Cl} \mathrm{L}^{-1}$ and very low electrolytic conductivity. There then occurred a small increase in the abundance and biomass of periphyton assemblages and phytoplankton accompanied by increased orthophosphate level. This suggests that the phosphorus may originate from the lake- 
bed sediments. These conditions favoured the development of planktonic cyanobacteria which attained the high proportion of $64.28 \%$ of the total biomass. There were also the high proportions of $85.93 \%$ diatoms found in the periphyton in pipes and $75.51 \%$ chlorophytes in epilithon. This increase in chlorophyte proportion was associated with a decrease in the amount of precipitation.

(2) In 2000 , the average monthly precipitation in the vegetative season registered $49 \mathrm{~mm}$ with a winter maximum of $53 \mathrm{~mm}$. Concurrently, the mean storm water inflow, the maximum chloride concentration of $97 \mathrm{mg} \mathrm{Cl} \mathrm{L}^{-1}$ and high electrolytic conductivity were recorded at the separators and in the pelagial. Following this, the maximum abundance of periphyton was observed in the pipes at the highest orthophosphate level, together with very low abundance and biomass of phytoplankton. This suggests that the high orthophosphate level may have favoured the development of periphyton in pipes. However, the high $47 \mathrm{mg} \mathrm{Cl} \mathrm{L}^{-1}$ chloride concentration in the pelagial, with a mean of 23 $\mathrm{mg} \mathrm{Cl} \mathrm{L}{ }^{-1}$ in the study period, could have limited phytoplankton development, and especially that of cyanobacteria (Zębek, 2014). In these conditions, the phytoplankton was dominated by diatoms at $58.26 \%$ of
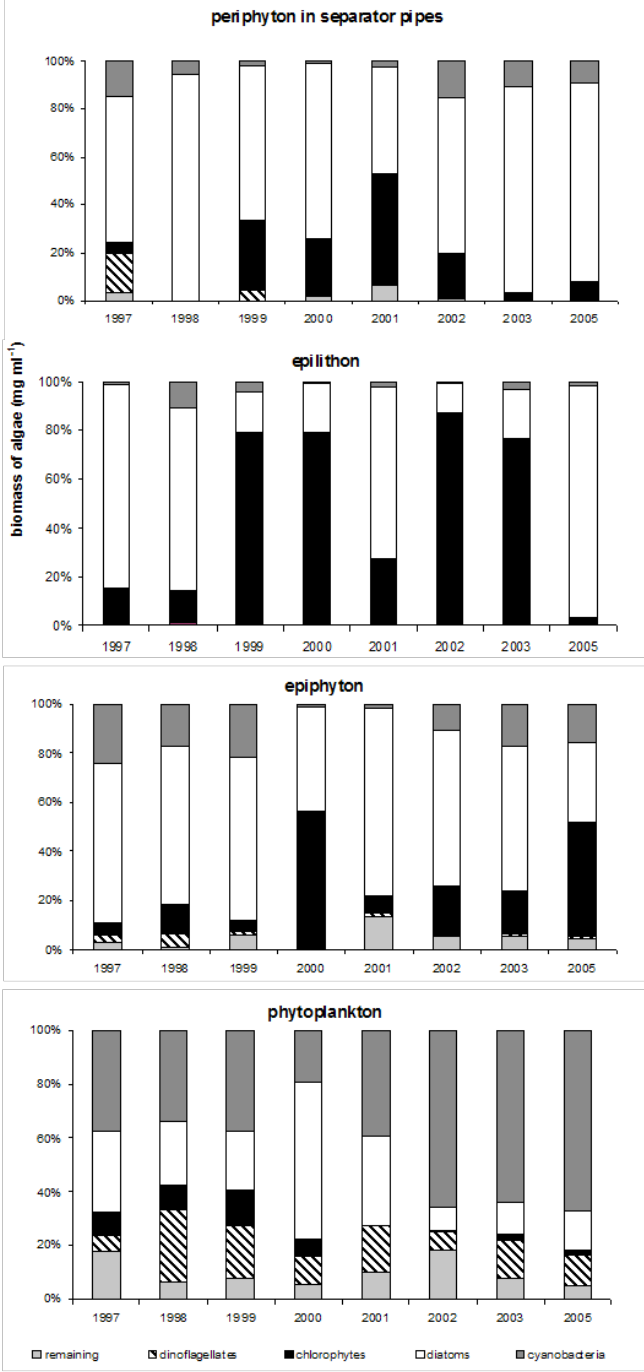

Fig. 3. The structure of taxonomic groups in the total biomass of periphyton and phytoplankton assemblages in Lake Jeziorak Mały in 1997-2003 and 2005. the total biomass. However, a predominance of 55.93\% chlorophytes was recorded in the epiphyton.

(3) In 2001, there was a high monthly precipitation of $69 \mathrm{~mm}$ in the vegetative season with a mean of $36 \mathrm{~mm}$ in winter. This was accompanied by large inflows of storm water, a moderate $39 \mathrm{mg} \mathrm{Cl} \mathrm{L}^{-1}$ chloride concentration, low electrolytic conductivity and a minimum level of orthophosphates at all sites. This was followed by decreased abundance 
of periphyton in the separator pipes and the maximum abundance of epiphyton and phytoplankton. This suggests that minimal nutrient concentrations at the separators adversely affected the assemblage development, and especially that of diatoms. A considerable proportion of chlorophytes, at $46.59 \%$ of the total biomass, was recorded in the periphyton in pipes, and the low chloride concentration did not limit cyanobacteria development. These latter accounted for $39.43 \%$ of the total phytoplankton biomass in the pelagial.

(4) In 1997, the maximum precipitation of $73 \mathrm{~mm}$ was recorded in the vegetative season with a mean value of $37 \mathrm{~mm}$ in the winter. This was accompanied by the largest inflow of storm waters, a high chloride concentration of $66 \mathrm{mg} \mathrm{Cl} \mathrm{L}^{-1}$ and high electrolytic conductivity and orthophosphate levels at the separators and at sites with stones. The maximum biomass of periphyton in the separator pipes and epilithon, together with minimum abundance and biomass of epiphyton and phytoplankton were then observed. This suggests that the high nutrient concentration at the separators favoured development of periphyton in pipes, and that the high chloride concentration limited cyanobacteria growth in the pelagial. Compared to other years, a significant proportion of cyanobacteria of allochtonic character was found in the periphyton in pipes, and this amounted to $15.12 \%$ of the total biomass. Meanwhile, the proportion in the pelagial registered $37.45 \%$ of the total phytoplankton biomass.

Similar situations to those in Lake Jeziorak Mały have been recorded by some authors. Irigoien at al. (2000) reported similar findings to those in situation (4) above, recording significant lower phytoplankton biomass in years with high water level. This was related to supplies of nutrients in a shallow eutrophic lake, as was the decrease in the phytoplankton biomass with high $\mathrm{N}$ and $\mathrm{P}$ concentrations (Nõges et al., 2003). An increase in phosphorus with a simultaneous decrease in phytoplankton biomass does not necessarily indicate that phosphorus plays an important role in the long-term control of phytoplankton growth. Rather, the maximum phosphorus concentration at increased water level suggests intensive resuspension from the lake sediments which enriches nutrients in the lake water, as discussed in situation (3) above. At low water level, when light becomes a limiting factor, phosphorus may be taken up by phytoplankton until nitrogen limitation begins (Nõges, Laugaste, 1998). According to Luttenton and Baisden (2006), intensive water mixing, substratum movement and increased water levels are common factors causing disruption to periphyton growth. The loss of periphyton biomass was observed to occur more rarely due to intensive mixing than to high water level, as expounded in situation (3), and also more rarely than substratum movements and gastropod grazing (Zębek et al., 2012).

\section{Species diversity and dominants of periphyton and phytoplankton assemblages}

Diversity at the trophic level is manipulated by taxonomic and functioning diversity, and it can be emphasized by ecosystem processes including productivity and nutrient inflow. Here, large and rapid changes in ecosystem processes can also be due to anthropogenic causes such as animal grazing (Thebault, Loreau, 2006). Because diversity is stimulated by both allogenic inflow of nutrients and saline waters and by autogenic inflow, changes between these inflow 

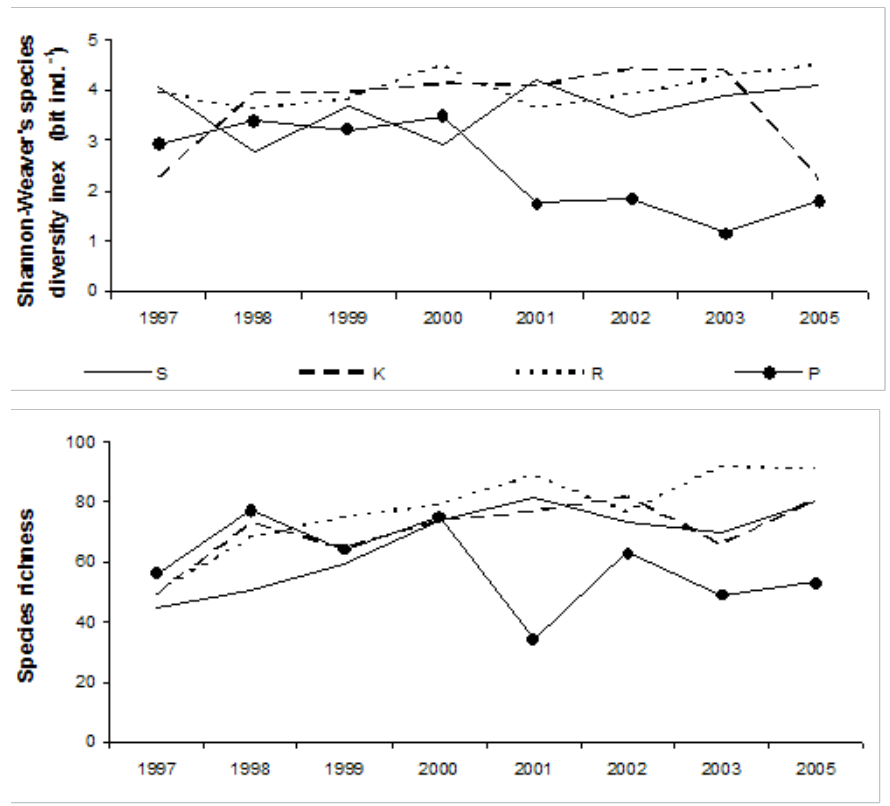

Fig. 4. Species diversity and taxa number of periphyton assemblages ( $\mathrm{S}$ - periphyton in separator pipes, $\mathrm{K}$ - epilithon, R - epiphyton) and phytoplankton (P) in Lake Jeziorak Mały in 1997-2003 and 2005.

types can influence the replacement of one species by another (Reynolds, 1993). Intensive mixing and fluctuations of water levels are also important factors affecting ecological processes in lakes, and also the species habitats and diversity (Wantzen et al., 2008). The fact that only few species' populations are able to establish themselves following very intense disturbances leads to minimum diversity. While a similar phenomenon can occur in normal circumstances, the highest diversity often succeeds intermediate disturbance frequency and/ or intensity (Sommer et al., 1993). A decrease in the number of taxa at the different disturbance frequencies or levels may be related to washing these taxa (Luttenton, Baisden, 2006). However, here in Lake Jeziorak Mały, differences in the species diversity of periphyton and phytoplankton assemblages in 1997-2003 and 2005 were observed to alter in conjunction with differing amounts of precipitation. For example, the highest Shannon-Weaver species diversity for periphyton in the separator pipes was recorded in 2001 at 4.1048 bit ind. $^{-1}$ and the largest taxa number of 82 (Fig. 4), when there was a high amount of precipitation, moderate chloride concentration and low electrolytic conductivity (Figs 1,2). These conditions favoured the development of large periphyton taxa numbers in pipes resistant to washing. This was supported by the low proportion of dominant Rhoicosphenia abbreviata which registered only $13.04 \%$ of the total abundance (Fig. 5). The assemblage was often also dominated by Navicula gregaria which is resistant to high amounts of organic matter (Zębek et al., 2012). However, in the very high rates of precipitation and storm water inflows in 1997, there was a record twofold lower number of 45 taxa, and this may have been due to washing of peri- 

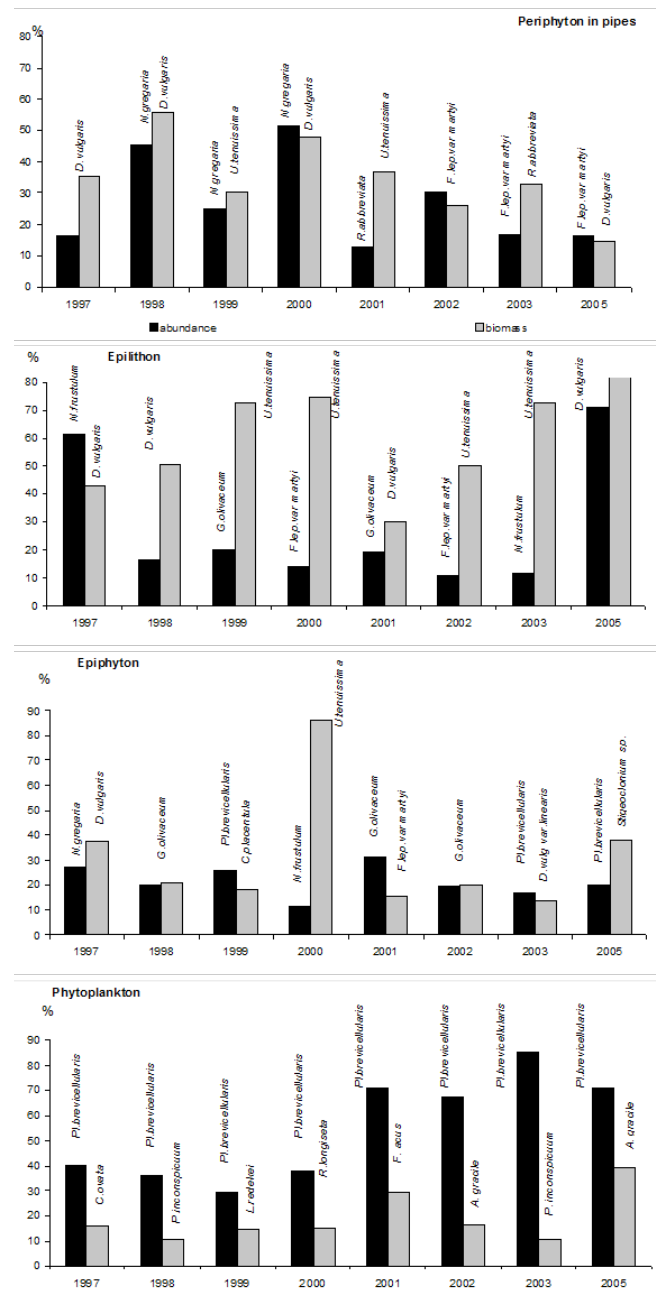

Fig. 5. The dominant taxa in the total abundance and biomass of periphyton and phytoplankton assemblages in Lake Jeziorak Mały in 1997-2003 and 2005. phyton in the separator pipes. The highest species diversity index for epilthon was recorded at 4.2747 bit ind. $^{-1}$ and 66 taxa in 2003 (Fig. 4), when there was the least precipitation and also increased orthophosphate levels in the lake water (Figs 1,2). At this time, the epilithon was dominated by Nitzschia frustulum with $11.19 \%$ of the total abundance (Fig. 5). However, the highest diversity for epiphyton and phytoplankton, at levels of 4.5256 and 3.4757 bit ind. $^{-1}$ with 79 and 75 taxa, was registered in 2000 at a moderate precipitation level (Fig. 4) and accompanying high electrolytic conductivity (Figs 1,2). Assemblage abundance was dominated at that time by $N$. frustulum (11.06\%) and Planktolyngbya brevicellularis (37.85\%, Fig. 5). This suggests that increased species diversity in the studied periphyton and phytoplankton assemblages was closely related to the amount of precipitation.

The specific seasonal succession of phytoplankton taxonomic composition was examined. Results showed that the lake's trophic level in the vegetative season is characterized by dominant algal taxa groups. This suggests that trends and intensities in ecological stress cause a sequence of harmonious trophic changes which effect continuous quantitative and qualitative changes in the floristic composition of phytoplankton. These effects continue until the lake's trophic type is altered. Although ecological succession can successfully occur within a determined trophic type area, it can also influence and support changes from one trophic type to another (Burchardt, 1993). Changes within the planktonic and periphytic algae species' composition are affected by light, nutrient supplies, changes in environmental conditions, grazing, $\mathrm{pH}$ and by allochtonic inflows and autogenic processes. In addition, phytoplankton is often dominated by cyanobacteria in open-wind activated systems. Jeziorak Mały is a polimictic lake (Jankowski, 1966), and according to Giziński (1978), it has a very high mixing 
index of 0.9 (Zębek, 2002). A clear predominance of cyanobacteria in the phytoplankton was recorded there (Fig. 3). Reynolds (1993) suggested that small diatoms and filamentous chlorophytes mainly occurred at high nutrient concentrations in eutrophic lakes where there was continuous water mixing. This phenomenon was also recorded in this study, where there was a predominance of small diatom forms especially in the periphyton in the separator pipes, and filamentous chlorophytes in the epilithon at high orthophosphate levels (Figs 1, 3, 5).

There was a number of species sharing dominance in periphyton abundance in the separator pipes in Lake Jeziorak Mały during this study period. These comprised the four diatom species of Diatoma vulgaris B or y, Navicula gregaria D onkin, Rhoicosphenia abbreviata (Agardh) Lange-Bertalot and Fragilaria leptostauron var. martyi (Héribaud) LangeB ertalot. There was also less phytoplankton, where the cyanobacterial species Planktolyngbya brevicellularis Cronberg \& Komárek dominated. Meanwhile, epilithon was dominated by Nitzschia frustulum (Kützing) Grunow in 1997 and 2000 and by Gomphonema olivaceum (Hornemann) Brébisson in 1999 and 2001, while epiphyton was dominated by Planktolyngbya brevicellularis in 1999, 2003 and 2005. The overall greatest variability of dominant species was recorded in the biomass of epiphyton. Here the domination was shared by the following seven species; Diatoma vulgaris, Gomphonema olivaceum, Cocconeis placentula Ehrenb, Fragilaria leptostauron var. martyi, Diatoma vulgaris var. linearis Grunow in Van He urck, Ulothrix tenuissima Kützing and Stigeoclonium sp., while the least biomass was recorded by Diatoma vulgaris and Ulothrix tenuissima species in the epilithon. In addition, the following phytoplankton shared dominance; Cyclotella comta (Ehrenberg) Kützing, Peridinium inconspicuum L e m m., Limnothrix redekei (Van Go or) Meffert, Rhizosolenia longiseta Z a ch a rias, Fragilaria acus (Kützing) Lange-Bertalot and Aphanizomenon gracile Lem m. (Fig. 5). According to some authors, the dominance of filamentous cyanobacteria changed with changing water levels. For example, Planktolyngbya limnetica registered its maximum abundance at low water level and Limnothrix redekei recorded its in high water levels (Irigoien et al., 2000, Nõges et al., 2003, 2010). Again, similar phenomena were observed in this research, where: (1) Planktolyngbya brevicellularis had the highest proportion of total phytoplankton abundance at $84.97 \%$ in the low precipitation of 2003 and (2) Limnothrix redekei dominated the total phytoplankton biomass at $14.53 \%$ in the high water levels of 1999 (Figs 2, 5). The greater species variability within periphyton assemblages is clearly considered to be related to changes in the environmental conditions caused by storm water flowing into the littoral zone.

\section{Dynamics of periphyton and phytoplankton assemblages in the vegetative season}

Seasonal changes in algae in natural water bodies are often interpreted as interactions between seasonal development and internal disturbances. The environmental conditions including water temperature, nutrient availability and disturbances such as those due to intensive storm-water inflows can regulate the rate of seasonal algae development (Reynolds, 1988). Grazing is also an important factor in periphyton growth, and this was observed in Lake Jeziorak Mały in 2001 and 2002, when a maximum summer biomass of gastropods accompanied a minimum epilithon biomass (Zębek et al., 2012). The maximum biomass of periphyton recorded in Lake Jeziorak Mały in spring and autumn, and the phytoplankton dominated by cyanobacteria in summer, are 

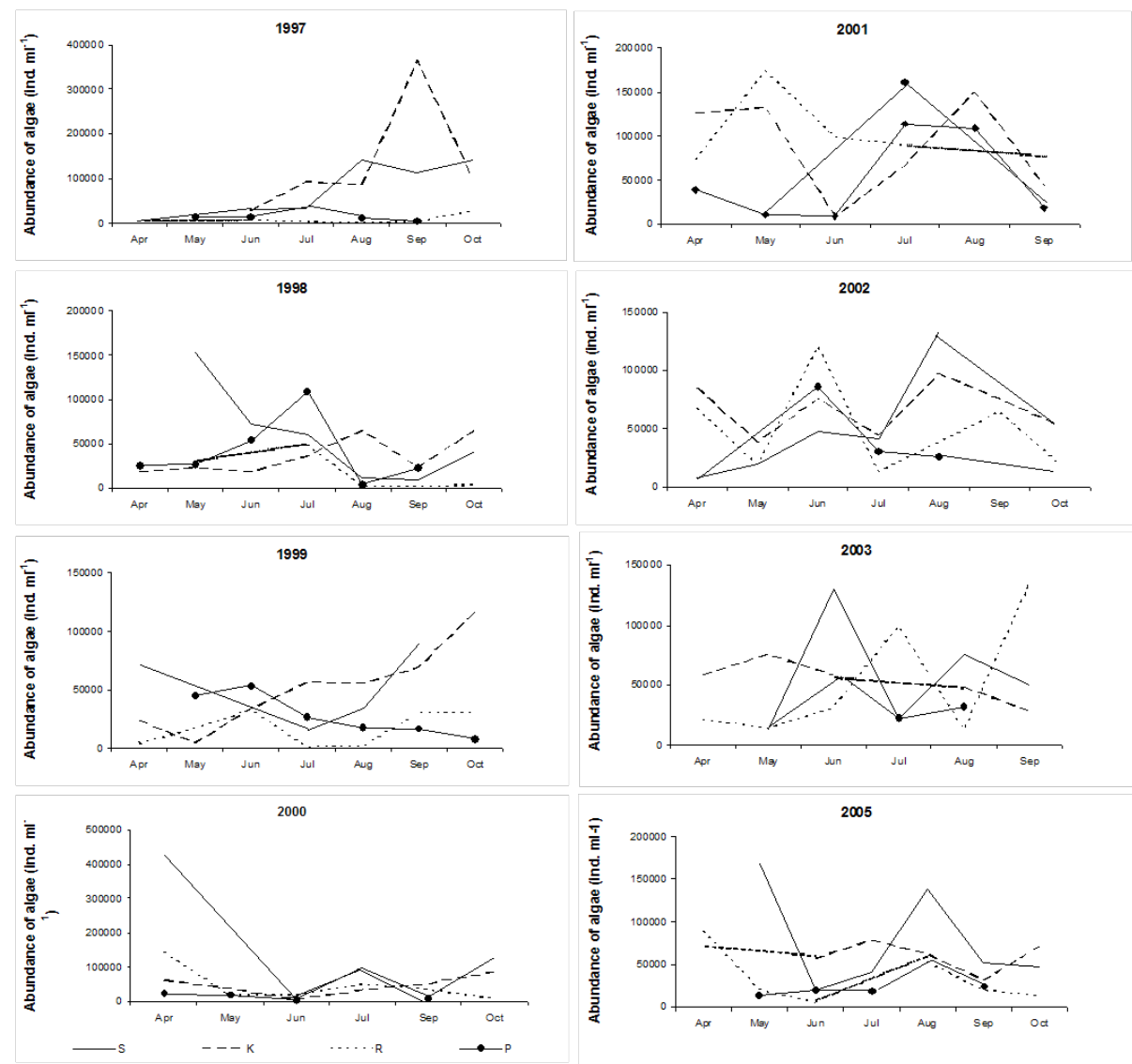

Fig. 6. Dynamics of abundance of periphyton assemblages ( $\mathrm{S}$ - periphyton in separator pipes, $\mathrm{K}$ - epilithon, $\mathrm{R}$ epiphyton) and phytoplankton (P) registered in Lake Jeziorak Mały from April to October 1997-2003 and 2005.

comparable to results from other studies examining eutrophic lakes (periphyton: Bohr, Miotk, 1979; Müller, 2000; Rodusky et al., 2001; Jöbgen et al., 2004; Asaduzzaman et al., 2010; and phytoplankton: Meffert, 1989; Romo, Miracle 1994; Nixdorf, 1994; Mischke, Nixdorf, 2003; KuczyńskaKippen et al., 2004; Kangro et al., 2005). Different dynamics of periphyton and phytoplankton assemblages were observed from April to October in 1997-2003 and 2005 in this study. The highest abundance and biomass of periphyton in the separator pipes and epilithon were found in 1997 following the initiation of separators and the accumulation of stones in the littoral zone. This was related to the rapid habitation of these substrata by periphyton with the accompanying highest average precipitation. These periphyton assemblages exhibited both the highest abundance and highest biomass at this time.

The largest variability was observed for periphyton in pipes where maximum assemblage abundance and biomass were recorded in different months in the studied years (April in 2000, 

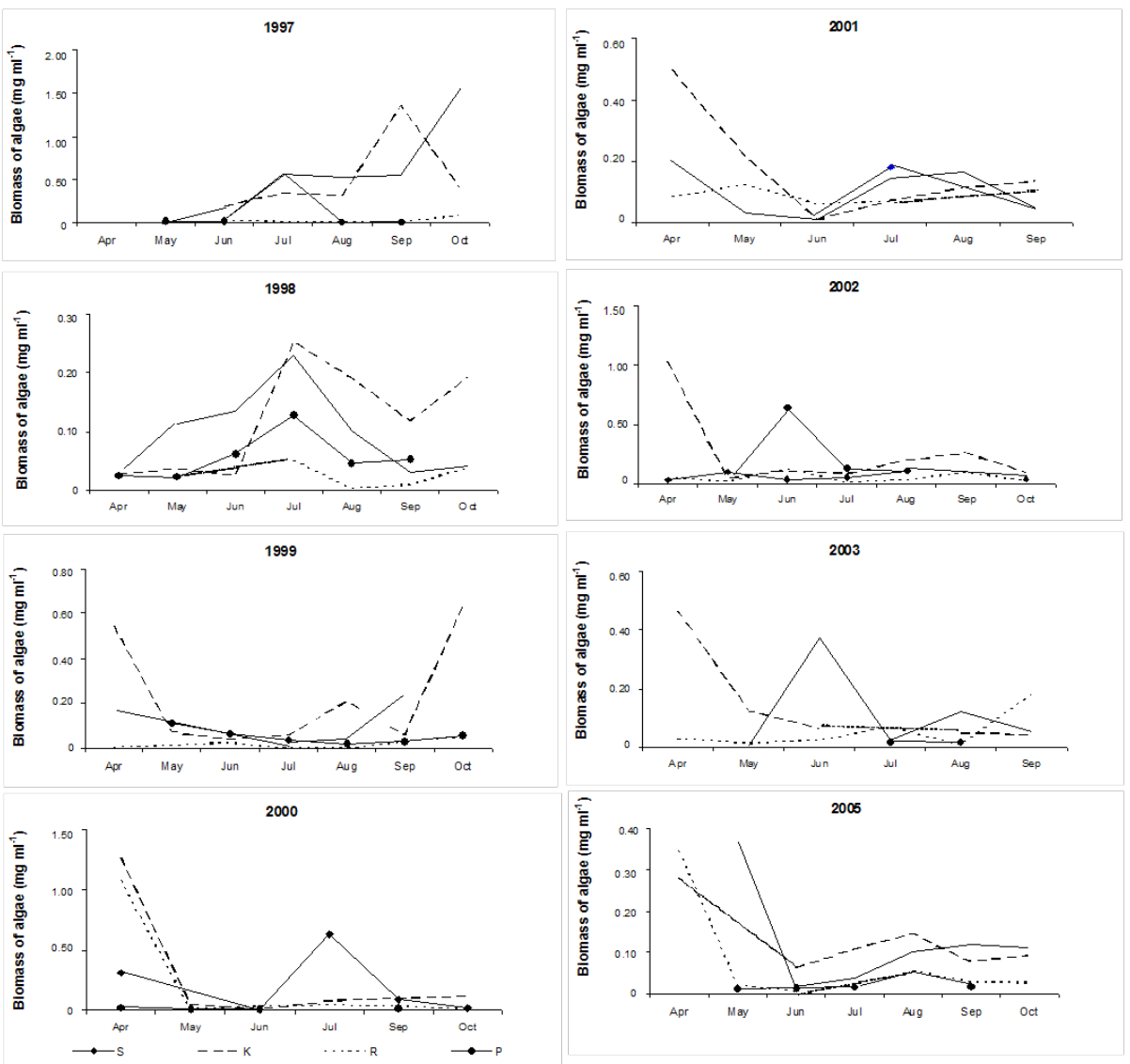

Fig. 7. Dynamics of biomass of periphyton assemblages ( $\mathrm{S}$ - periphyton in separator pipes, $\mathrm{K}$ - epilithon, $\mathrm{R}$ epiphyton) and phytoplankton (P) registered in Lake Jeziorak Mały from April to October 1997-2003 and 2005.

May in 1998 and 2005, June in 2003, July in 1998, 2000 and 2001; August in 2002 and 2001, September in 1997 and October in 1999). This phenomenon is most likely related to the greatest variability in environmental conditions at the separators caused by polluted storm-water inflows, which of course in this case was the result of increased precipitation (Zębek, 2014). The effects included high nutrient concentrations of $\mathrm{PO}_{4}, \mathrm{~N}_{\text {tot }}$ and chlorides following the winter season. Epilithon attained maximum abundance in the autumn seasons of September 1997 and October 1998, 1999, 2000 and 2005, and maximum biomass in the spring seasons of April 2001, 2002, 2003 and 2005 and May 2003 (Figs 6, 7). High nutrient concentrations were recorded at the sites with stones during these periods, and this may have favoured epilithon development (Fig. 1). In addition, the maximum abundance and biomass of epiphyton and phytoplankton were also registered in these identical periods. However, the largest variabilities for epiphyton were recorded in April 2000 and 2005, May 2001, June 1999 and 2002, July 1998, September 2003, and October in 1997. 
These exceeded the variabilities for phytoplankton registered in June 1999 and 2002, in July 1997, 1998, 2000 and 2001 and in August 2003 and 2005 (Figs 6, 7). Similar orthophosphate and electrolytic conductivity dynamics were recorded at sites with macrophytes, and since these dynamics also occurred in the pelagial, they most likely also affected the assemblages there (Fig. 1).

Finally, the enormous diversity in quantitative and qualitative data for periphyton in the separator pipes, epilithon, epiphyton and phytoplankton in Lake Jeziorak Mały in 1997-2003 and 2005 , and especially in vegetative season months, highlights the great sensitivity of the studied prokaryotic and eukaryotic organisms. This sensitivity is considered to be closely related to the mean monthly precipitation, and this clearly demonstrates that the assemblages inhabiting separator pipes and stones have quite different succession rates to those of planktonic algae.

\section{Acknowledgements}

I wish to thank Prof. Lubomira Burchardt for many valuable suggestions on the previous version of the manuscript.

\section{References}

Asaduzzaman, M., Rahman, M.M., Azim, M.E, Islam, M.A., Wahab, M.A., Verdegem, M.C.J. \& Verreth J.A.J. (2010). Effects of $\mathrm{C} / \mathrm{N}$ ratio and substrate addition on natural food communities in freshwater prawn monoculture ponds. Aquaculture, 306, 127-136. DOI: 10.1016/j.aquaculture.2010.05.035.

Azim, M.A., Verdegem, M.C.J., van Dam, A.A. \& Beveridge C.M. (2005). Periphyton: ecology, exploitation and management. Oxfordshire: CABI Publishing.

Battarbee, R.W. (1979). Diatoms in lake sediments. In B.E. Berglund (Ed.), International Geological Correlation Programme Project 158, Paleohydrological Changes in the Temperate Zone in the Last 15,000 Years (pp. 177-225). Subproject B, Lake and Mire Environments. Lund: Department of Quaternary Geology.

Bohr, R. \& Miotk G. (1979). The primary production of periphytic algae in the south part of the Jeziorak Lake. Acta Universitatis Nicolai Copernici, 47(11), 13-17.

Burchard, L. (1993). Bioindication in the assessment of lake ecosystem. In L. Burchard (Ed.), Interdisciplinary investigations of freshwater ecosystems. Idee Ekologiczne, 3(2), 39-44.

Danilov, R.A. \& Ekuland N.G.A. (2001). Comparison of usefulness of three types of artificial substrata (glass, wood and plastic) when studying settlement pattern of periphyton in lakes of different trophic status. J. Microbiol. Methods, 45, 167-170. DOI: 10.1016/S0167-7012(01)00247-0.

France, R. (1995). Differentiation between littoral and pelagic food webs in lake using stable carbon isotopes. Limnol. Oceanogr., 40(7), 1310-1313.

Giziński, A. (1978). Significance of benthal fauna as indicator of eutrophication degree in lakes. Verhandlungen des Internationalen Verein Limnologie, 20, 997-999.

Grzesiak, M. \& Domańska W. (1998-2004, 2006). Protection of environment. Statistical information and study. Warsaw: Statistical Publishing Establishment.

Hansson, L.A. (1990). Quantifying the impact of periphytic algae on nutrient availability for phytoplankton. Freshw. Biol., 24, 265-273. DOI: 10.1111/j.1365-2427.1990.tb00707.x.

Irigoien, X., Harris, R.P., Head, R.N. \& Harbour D. (2000). North Atlantic Oscillation and spring bloom phytoplankton composition in the English Channel. J. Plankton Res., 22, 2367-2371. DOI: 10.1093/plankt/22.12.2367.

Jankowski, A. (1966). Studies on thermal-oxygen conditions in the Lake Jeziorak. Acta Universitatis Nicolai Copernici, $16(2), 17-31$.

Jöbgen, A.M., Palm, A. \& Melkonian M. (2004). Phosphorus removal from eutrophic lakes using periphyton on submerged artificial substrata. Hydrobiologia, 528, 123-142. DOI: 10.1007/s10750-004-2337-5.

Kangro, K., Laugaste, R., Noges, P. \& Ott I. (2005). Long-term changes and seasonal development of phytoplankton in a strongly stratified, hypertrophic lake. Hydrobiologia, 547, 91-103. DOI: 10.1007/s10750-005-4151-0.

Kuczyńska-Kippen, N., Messyasz, B. \& Nagengast B. (2004). The structure of the periphytic communities of the Wielkowiejskie Lake. Roczniki Akademii Rolniczej w Poznaniu, 358(7), 175-191.

Lampert, W. \& Sommer U. (1996). Ecology of inland waters. Warsaw: PWN Press. 
Meffert, M.E. (1989). Planktic unsheathed filaments (Cyanophyceae) with polar and central gas vacuoles. II. Biology, population dynamics and biotopes of Limnothrix redekei (Van Goor) Meffert. Arch. Hydrobiol., 116(3), 257-282.

Mischke, U. \& Nixdorf B. (2003). Equilibrium phase conditions in shallow German lakes: How Cyanoprokaryota species establish a steady state phase in late summer. Hydrobiologia, 502, 123-132. DOI: 10.1023/B:HYDR.0000004275.81490.92.

Müller, U. (2000). Periphytic primary production during spring. A sink of source of oxygen in the littoral zone? Limnologica, 30, 169-174. DOI: 10.1016/S0075-9511(00)80012-2.

Nixdorf, B. (1994). Polymixis of a shallow lake (Grober Müggelsee, Berlin) and its influence on seasonal phytoplankton dynamics. Hydrobiologia, 275-276, 173-186. DOI: 10.1007/BF00026709.

Nixdorf, B., Mischke, U. \& Rücker J. (2003). Phytoplankton assemblages and steady state in deep and shallow eutrophic lake - an approach to differentiate the habitat properties of Oscillatoriales. Hydrobiologia, 502, 111-121. DOI: 10.1023/B:HYDR.0000004274.65831.e5.

Nõges, P. \& Laugaste R. (1998). Seasonal and long-term changes in phytoplankton of Lake Võrtsjärv. Limnologica, 28(1), 21-28.

Nõges, P., Mischke, U., Laugaste, R. \& Solimini A.G. (2010). Analysis of changes over 44 years in the phytoplankton of Lake Võrtsjärv (Estonia): the effect of nutrients, climate and the investigator on phytoplankton-based water quality indices. Hydrobiologia, 646, 33-48. DOI: 10.1007/s10750-010-0178-y.

Nõges, T., Nõges, P. \& Laugaste R. (2003). Water level as the mediator between climate change and phytoplankton composition in a large shallow temperate lake. Hydrobiologia, 506-509: 257-263. DOI: 10.1023/B:HYDR.0000008540.06592.48.

Odum, E.P. (1969). The strategy of ecosystem development. Science, 164, 262-270. DOI: 10.1126/science.164.3877.262.

Reynolds, C.S. (1988). The concept of ecological succession applied to seasonal periodicity of freshwater phytoplankton. Verhandlungen des Internationalen Verein Limnologie, 23, 683-691.

Reynolds, C.S. (1990). Temporal scales of variability in pelagic environmental and the response of phytoplankton. Freshw. Biol., 23, 25-53. DOI: 10.1111/j.1365-2427.1990.tb00252.x.

Reynolds, C.S. (1993). Scales of disturbance and their role in plankton ecology. Hydrobiologia, 249, 157-171. DOI: $10.1007 /$ BF00008851.

Rodusky, A.J., Steinman, A.D., East, T.L., Sharfstein, B. \& Meeker R.H. (2001). Phytoplankton nutrient limitation and other potential growth - controlling factors in Lake Okeechobee, U.S.A. Hydrobiologia, 448, 27-39. DOI: 10.1023/A:1017529432448.

Romo, S. \& Miracle R. (1994). Long-term phytoplankton changes in a shallow hypertrophic lake, Albufera of Valencia (Spain). Hydrobiologia, 275-276, 153-164. DOI: 10.1007/BF00026707.

Rott, E. (1981). Some results from phytoplankton counting intercalibrations. Schweizerische Zeitschrift für Hydrologie, 43, 34-62. DOI: 10.1007/BF02502471.

Shannon, C.E. \& Weaver W. (1949). The mathematical theory of communication. Urbana.

Sommer, U., Gliwicz, Z.M., Lampert, W. \& Duncan A. (1986). The PEG -model of seasonal succession of planktonic events in fresh waters. Arch. Hydrobiol., 106(4), 433-471.

Sommer, U., Padisak, J., Reynolds, C.S. \& Juhasz-Nagy P. (1993). Hutchinson's heritage: the diversity - disturbance relationship in phytoplankton. Hydrobiologia, 249, 1-7. DOI: 10.1007/BF00008837.

Szlauer, L. (1996). Determination method of the volume of periphyton components. Pol. Arch. Hydrobiol., 43(1), 3-8.

Thebault, E. \& Loreau M. (2006). The relationship between biodiversity and ecosystem functioning in food webs. Ecol. Res., 21, 17-25. DOI: 10.1007/s11284-005-0127-9.

Vogel, A., Beier, T., Braun, J. \& Raeder U. (2005). Does the process of drying submerged macrophytes affect community structure and composition of epiphytic diatoms? Hydrobiologia, 541, 237-240. DOI: 10.1007/s10750-004-4669-6.

Wantzen, K.M., Rothaupt, K-O., Mörtl, M., Cantonati, M., G.-Toth, L. \& Fischer P. (2008). Ecological effects of water-level fluctuations in lakes: an urgent issue. Hydrobiologia, 613, 1-4. DOI: 10.1007/s10750-008-9466-1.

Zębek, E. (2002). Influence the restorative works on phytoplankton in the urban Lake Jeziorak Mały. Doctor dissertation.

Zębek, E. (2009). Seasonal changes in net phytoplankton in two lakes with differing morphometry and trophic status (northeast Poland). Archives of Polish Fisheries, 17, 267-278. DOI: 10.2478/v10086-009-0019-7.

Zębek, E., Bonar, A. \& Szymańska U. (2012). Periphytic diatom communities in the littoral zone of the urban lake Jeziorak Mały (Masurian Lake District, Poland). Ekológia (Bratislava), 31(1), 105-123. DOI: 10.4149/ekol_2012_01_105.

Zębek, E. (2013). Differentiation of periphyton and phytoplankton assemblages in anthropogenically transformed conditions of littoral zone in a shallow urban lake (Lake Jeziorak Mały, Poland). Applied Ecology and Environmental Research, 11(3), 323-342.

Zębek, E. (2014). Response of cyanobacteria (phytoplankton) and periphyton to stormwater in shallow urban lake (in print). 